\title{
YALE
}

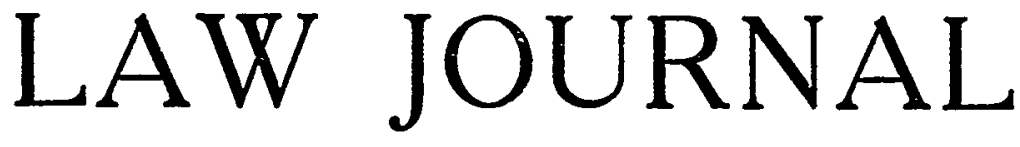

\begin{tabular}{lll}
\hline \hline Vol. XXVI & JANUARY, 1917 & No. 3 \\
\hline \hline
\end{tabular}

\section{OFFER AND ACCEPTANCE, AND SOME OF THE RESULTING LEGAL RELATIONS}

In the study and the practice of the law, our constant problem is: what legal relations are the result of facts that occur; or, starting from the other direction with a given set of legal relations (such as a contract, or a debt, or the ownership of land) our problem is: what facts will operate to cause such a result? One may take either starting point; and indeed for the best results, it is necessary to take both, alternately working forward and back, correcting and amplifying our necessarily tentative conclusions. In the present article, the starting point will be the contractual relations themselves, leading back to a consideration of some of the facts and intermediate relations that various forms?

The term contract has been used without much discrimination to refer to three different things: (I) the series of operative acts of the parties expressing their assent and resulting in new legal relations; (2) the physical document executed by the parties as an operative fact in itself and as the lasting evidence of their having performed the necessary operative acts; (3) the relations resulting from the operative acts, consisting of a right or right in personam and the corresponding duties, accompanied by certain powers, privileges and immunities. ${ }^{1}$ Clearness of

I For a masterly analysis and classification of jural relations, see an article on Some Fundamental Legal Conceptions as Applied in Judicial Reasoning, in 23 Yale Law JournaL, 16, by Professor W. N. Hohfeld of the Yale School of Law. 
thought requires that whenever the term is used, one particular meaning should be consciously adopted and clearly expressed. Very likely it would be most convenient generally to define contract in sense (3), as the legal relations between persons arising from a voluntary expression of intention, and including at least one primary right in personam, actual or potential, with its corresponding duty. Unless otherwise indicated, the term contract will be used herein with this meaning.

In determining whether or not a contract exists in any given case, one of our problems is historical in character. What were the facts? What were the acts of the parties and the circumstances that surrounded them? When these have been ascertained the next step is analytical. Immaterial facts must be eliminated, and the rest must be classified as either evidential or operative. The operative facts are those that cause the existence of those legal relations called a contract.

This analysis can only be made, and must be made, with reference to the law of contract. This law is a part of the general legal system under which we live, enforced by the societal organization of which we are part. What the rules of this society are, can be determined only by induction from the judgments and decrees and pronouncements of the past. Under the existing legal system no legal relation is deemed contractual in the absence of certain voluntary acts on the part of two contracting parties. What acts are those which will cause society to come forward with its strong arm? They may well be described as operative or causative, for they are necessary antecedents to the creation of those legal relations and societal

\footnotetext{
2 Compare the following definitions. "The most popular description of a contract that can be given is also the most exact one; namely, that it is a promise or set of promises which the law will enforce. The specific mark of a contract is the creation of a right, not to a thing, but to another man's conduct in the future." "Every agreement and promise enforceable by law is a contract." Wald's Pollock, Contracts (3d ed.) pp. I, 2.

A contract is "an agreement enforcible at law, made between two or more persons, by which rights are acquired by one or more to acts or forbearances on the part of the other or others." Anson, Contracts (2d Am. ed., Huffcut) p. II.

"The act alone is the contract, the resulting contractual relation is quite a different thing." Holland, Jurisprudence (1oth ed.) p. 25I. See also Bentham's classification, Works, III, I9I.
} 
guaranty of compulsion called contract. The analysis of these acts into offer and acceptance, customarily made by writers on contract law, is a convenient one.

An offer is an act on the part of one person whereby he gives to another the legal power of creating the obligation called contract: An acceptance is the exercise of the power conferred by the offer, by the performance of some other act or acts. Both offer and acceptance must be acts expressing assent.

The act constituting an offer and the act constituting an acceptance may each consist in a promise. A promise is an expression of intention that the promisor will conduct himself in a specified way in the future, with an invitation to the promisee to rely thereon. If only one of the acts has this character, the contract is unilateral. If both acts have this character, the contract is bilateral. If neither of the acts has this character, the new set of legal relations, if any exist, is not called obligation. In such case there is no contract in sense (3) adopted above, although there may be one in either of the other senses. Each of these three cases will be discussed below. In none of these cases will the expected legal relations be created unless the acts of the parties comply with the rules relating to mutual assent, consideration, form, capacity of parties, and legality of object. Only certain rules relating to mutual assent will be considered here.

\section{BARTER}

A mutual, present exchange of lands or chattels creates no contractual duty. If $\mathrm{A}$ has apples to sell and $\mathrm{B}$ has money, $\mathrm{A}$ may offer the apples to $B$ for the money. $B$ may accept by delivering to $A$ the possession of the money. Such a transaction is a barter. The character of the commodities exchanged is not material. Such a transaction creates new physical relations, and in an organized society it creates new legal relations. These new relations arise by the voluntary action and consent of the two parties, but there is no special right in personam. There is a contract in sense (I) described above, and a documentary bill of sale would be a contract in sense (2), but there is no contract in sense (3). After such a transaction the apples "belong" to $B$ and the money to $A$; this means that organized society has created numerous legal relations between each party and every other member of society. A and B are said to have rights in rem, a term that is useful even though likely to mislead some into 
thinking that such a right is a physical relation to the res. The legal relations created are not special relations between $A$ and $B$; they involve all persons alike, and exist in total independence of their voluntary action or consent. If after the transaction $A$ should forcibly deprive $B$ of the apples sold to him, he is committing no different wrong from that committed by $\mathrm{X}$ if he should do the same, and he is subject to no different penalties. After such a transaction the legal relations between $A$ and $B$, arising by their consent, are precisely like the legal relations existing between $\mathrm{X}$ and $\mathrm{B}$, although $\mathrm{X}$ has consented to nothing. Such a transaction is often called an executed contract, but it is better described as a barter or an exchange of goods.

GIFT

If $A$ has lands or chattels and executes a gift to $B$, which $B$ accepts, there are acts of offer and acceptance and there is mutual assent, yet no contractual obligation is created. As in the case of a barter, the only rights involved are property rights or rights in rem. The only duties created are those general duties, binding upon non-participating persons as well as upon A. No special right in personam is created. A's rights in rem and B's former duties are extinguished, and in lieu thereof similar rights are created in B and similar duties devolve upon A. The same may be said of their respective privileges, powers, immunities, and their correlatives. Thus, there are new legal relations, arising from voluntary acts of offer and acceptance. and such acts would fulfil the first definition of a contract given above. A paper "deed of gift" would satisfy the second definition. The resulting legal relations, however, should not be described as contractual, according to definition (3). All other persons, and not merely $A$ and $B$, are parties to these new relations.

\section{CONTRAC'}

If $A$ has apples (or land) to sell, and $B$ has no money, a barter of apples for money is not possible; but $A$ may be willing to deliver his apples to B in return for B's promise to pay money in the future. If $B$ agrees to this, receives the apples and promises to pay the money, a new physical relation exists as to the apples but not as to the money. As in the case of barter. or gift, society creates numerous relations between $B$ and all other persons; as to the apples, he has rights in rem against such other persons. B's rights are property rights and not contract 
rights. But the position of $A$ is very different from that of barter. A has no money, and no rights in rem, good as against third persons who are not consenting; but a promise has been made to $A$ by $B$, the fulfilment of which is commanded by organized society. If $B$ fails to keep his promise, society will at A's request exercise compulsion against $B$, but will exercise compulsion against no other person. Special legal relations exist between $A$ and $B, A$ having a claim against $B$ that he has against no other person, and $B$ having a duty that rests upon no other person. These relations, with certain others that will not here be discussed, ${ }^{3}$ constitute the obligation; and since they arise from expressions of mutual consent, they are contract. A's special right against $B$ is called a right in personam.

UNILATERAL AND BILATERAL CONTRACTS

If the acts of $A$ and $B$ are such as to create a right or rights in personam, actual or potential, in favor of $A$ and against $B$, but no such right in favor of $B$ against $A$, the contract is called unilateral. If they create mutual rights in personam with their corresponding duties, the contract is bilateral. It has sometimes been said that a contract must be binding on both parties or that it is binding on neither, that mutuality of obligation is required; but this is a loose and inaccurate statement. It has no application whatever in the case of unilateral contracts. ${ }^{4}$

(I) If A makes a promise in writing to pay B $\$ 100$ and signs, seals, and delivers the document, a unilateral obligation is created. It creates a duty resting on $A$ and a right possessed by $B$.

(2) If $A$ accepts a bill of exchange drawn upon him by $B$ in

3 They are, however, of vital importance, both practically and logically. See Hohfeld, loc. cit. note I, supra.

"Courts very frequently use the term "unilateral" to refer to a promise that is without consideration, especially in those cases where mutual promises have been given, but one of them is illusory: as where A offers a promise to carry all the milk that B may care to ship, at fixed rates, and $B$ accepts the offer and promises to pay those rates for all milk shipped by him with $A$. It is not unlikely that this is the prevailing usage, but it is illogical and should be abandoned. Both $A$ and $B$ have made promises, but neither promise has resulted in either a right or a duty. There is no obligation, unilateral or otherwise. $A$ has made an offer and perhaps $B$ still has a power of acceptance. This one new relation might be described as unilateral; but the same may be said of any offer, and it is not customary to do so. See Morrow v. So. Express Co. (I897) IOI Ga. 810; Rehm-Zeiher Co. v. Walker (1913) I56 Ky. 6; American Refrig. Co. v. Chilton (Ig00) 94 Ill. App. 6. 
favor of $C$, a right springs up in $C$ and a duty rests on $A$. This obligation between $A$ and $C$ is unilateral.

(3) If $A$ gives to $B$ his I O U in return for money loaned by $B$, there is a similar unilateral contract.

(4) If $B$ offers to A a conveyance of property in land or chattels for a promise, and the offer is accepted, the contract is unilateral. For example, B says to A, "This black horse is yours as he stands in return for your promise to pay me $\$ 100$ in 30 days." A replies, "I accept." This is an executed sale on credit without warranty. B's offer confers upon A the power to make the horse his own by making the requested promise. No duty, special to himself, rests upon the offeror, and the offeree gets no right in personam. The offeror gains a right in personam and the offeree gets instantly certain right in rem.

(5) A offers a promise of a reward of $\$ 100$ to anyone who will arrest X. B, with knowledge of this offer and with intent to accept it, arrests $X$. A unilateral obligation at once arises. ${ }^{\circ}$

(6) A writes to B, "Ship me 2 cars XX flour via B. \& O., at once, price \$1o per bbl. C.O.D." $B$ ships at once as requested. ${ }^{7}$

((7) A sends his brother to $B$ with the following letter of credit, "Let Harry have $\$ 100$ and I will guarantee repayment in 30 days." $B$ advances $\$ 100$ as requested. ${ }^{8}$

(8) A promises $B$ to pay him a salary at the rate of $\$ 10,000$ a year for B's services as superintendent. B may recover at the specified rate for such service as he thereafter renders, but the hiring is a hiring at will. ${ }^{\circ}$

\footnotetext{
${ }^{5}$ Mactier v. Frith (1830) 6 Wend. (N. Y.) ro3. Langdell, Summary, sec. I4, suggests that in this case no promise was necessary, because a clebt would arise on Mactier's acceptance of the brandy; but the writer believes that such an acceptance necessarily involves a promise to pay, in fact, and that without such a promise the offeror did not intend title to pass.

${ }^{6}$ See Willians v. West Chi. St. Ry. (1901) rgr Ill. 610; Williants v. Carwardine (1833) 4 B. \& Ad. 62I; Biggers v. Ozen (1887) 79 Ga. 658; Shuey v. U.S. (1875) 92 U. S. 73.

${ }^{7}$ See Wood v. Benson (183I) 2 Cr. \& J. 44; Challenge Wind Mill Co. v. Kerr (1892) 93 Mich. 328; Wheat v. Cross (1869) 3I Md. 99.

${ }^{8}$ Lascelles v. Clark (I9I0) 204 Mass. 362; Lennox v. Murphy (1898) I7I Mass. 370; Eddowes v. Niell (I793) 4 Dall. (U. S.) 133; Bishop v. Eaton (1894) 16r Mass. 496; Offord v. Davics (1862) I2 C. B. (N. S.) 748.

${ }^{9}$ Martin v. N. Y. Life Ins. Co. (I895) 148 N. Y. I17; Harper v. Hassard (1873) I13 Mass. 187; Stensgaard v. Smith (1890) 43 Minn. II; Orr v. Ward (1874) 73 III. 318.
} 
It has been said that unilateral contracts are made either by an offer of a promise for an act or by an offer of an act for a promise. ${ }^{10}$ This means, although the descriptive words are not exact, that the single duty may rest on the offeror, the right being in the offeree, or vice versa. The words are inexact, because the making of a promise is itself an act. All offers are acts and all acceptances are acts, whether the resulting legal relations are property as in the case of a barter, or constitute a contractual obligation, either unilateral or bilateral. In example (I) above, the offeror makes a promise and undertakes a duty, but he requests no act whatever as an equivalent. The only act on the part of the offeree is such an act of acceptance of the physical document as may be necessary to constitute a legally effective delivery by the offeror. The duty is on the offeror.

In example (2), $C$ makes the offer when he presents the bill to A for acceptance. He thereby confers upon $A$ the legal power of binding himself alone to pay a sum of money. In presenting the bill $\mathrm{C}$ does an act, but he is not offering this act as the legal equivalent and agreed return for A's promise. There is no offer of an act for a promise, but the act of the offeror was necessary before the offeree could undertake the duty.

Example (3) is a case where it does not clearly appear which one made the offer. If $A$ offered his $I O U$ to be accepted by a transfer of money, it was an offer of a promise for an act. If $B$ offered a transfer of the money in return for the $I O U$, the case is just like example (4), except that there is paper evidence of A's promise.

Example (4) is a case where the duty is assumed by the offeree. B's act has been unhappily described as an offer of an act for a promise. $B$ does indeed do an act when he makes the offer just as any offeror must necessarily do; but he does not offer the act, he does the act. This act is completely performed even before $A$ hears of it and perhaps long before $A$ makes his promise. This act, regarded as in itself the consideration for A's promise, would be past consideration. The effect of B's act in making the offer is to confer upon A a power to create new legal relations. It produces this effect instantly and in so doing is wholly exhausted. The exercise of this power requires no further act upon B's part; it requires merely acceptance by A. The legal effect of this acceptance is the instant extinction

10 Anson, Contracts (2d ed., Huffcut) sec. 22. 
of B's rights in rem and other property relations in respect of the horse and the creation in $\mathrm{A}$ of similar rights and relations. The consideration for A's promise is this substitution of rights, and it is this substitution that is offered in return for the one right in personam to be created by A's promise.

Examples (5), (6) and (7) are all cases where a promise is offered for an act. That is, A by promissory words gives to B the power of creating in himself a right in personam as against A by doing an act or acts which $A$ desires to be done. In (5) this act is one affecting the physical and legal relations of $X$, a third party. In (6) B's act effects a substitution of property, A becoming owner of the flour. It also effects a physical change in the location of the goods. In (7) B's act confers property upon Harry, and extinguishes such property in B. It gives B in return a right in personam against $A$, enforcible after 30 days.

A bilateral contract is made in exactly the same way as is a unilateral contract or a barter. The offeror does an act conferring a power upon the offeree, and the offeree does the act that constitutes the exercise of the power. The legal result, however, is a relation consisting of mutual rights and duties, special and personal in character. The following are examples of bilateral contracts :

(9) A says to B, "I promise to serve you as bookkeeper for one month in return for your promise to pay me \$100." $B$ replies, "I accept."

(Io) A writes to B, "I promise to convey Blackacre to you on June Ist in return for your promise to pay me $\$ 1,000$ at that time. You may accept by cable, using the one word 'Blackacre'." $B$ sends the cable despatch "Blackacre," as requested.

In case (9) the acts of offer and acceptance are oral promissory words. In case (10) the offer is the act of writing and the further acts whereby this writing is brought to the offeree. The acceptance consists of acts by $B$, whereby he directs the cable company to transmit the word "Blackacre." These acts by B would not customarily amount to a promise to pay $\$ 1,000$, but in this case they do become such a promise because A will so interpret them and $B$ knows it. In the same way any other act, in itself meaningless, may be specified and may thereby become a return promise.

It is not always an easy matter to determine whether a contract is in fact unilateral or bilateral. Frequently, this determination will have very important results, especially where the offeror has 
attempted to revoke his offer as explained elsewhere. The form of words used by the parties is not at all conclusive, when examined out of their setting and with the aid of nothing but a dictionary. The meaning of words, as used by the parties to a contract, cannot be determined with mathematical certainty; and the judge who is most certain to do injustice is the pedant who holds contractors to meticulous accuracy in the usage of words and in the construction of sentences. ${ }^{11}$

It can hardly be said that courts are often pedantic in this matter, though it is possible that professors of law may be. The distinction between unilateral and bilateral is not even yet very thoroughly grasped by the multitude of lawyers, a fact which leads them to repeat again and again the erroneous statement that one cannot be bound unless the other is bound. The judges, therefore, are not in general too likely to hold that a proposed contract is unilateral when the parties meant it to be bilateral. ${ }^{12}$

11 "'The logic of the portion of the opinion . . . . above quoted, from the standpoint of the grammarian and verbal precision, is unassailable; but it may be questioned whether so literal, narrow, and technical a construction ought to be put upon such an ordinary business communication." Bauman v. McManus (I907) $75 \mathrm{Kan}$. Іоб. "In interpreting a declaration of intention, the real intention is to be looked for and it is not to be tied to the literal sense of the expression." German Civil Code, sec. I33.

12 "Whenever circumstances arise in the ordinary business of life in which if two persons were ordinarily honest and careful the one of them would make a promise to the other, it may properly be inferred that both of them understood that such a promise was given and accepted." $E x$ parte Ford (1885) I6 Q. B. D. 305, 307. In Mapes v. Sidney (1623) Cro. Jac. 683 , the defendant promised to pay the debt of J. S. to the plaintiff in consideration that the plaintiff would forbear to sue J. S. Plaintiff alleged that he forbore per magnum tempus. Winch and Hutton, J.J., thought this bilateral, the plaintiff having promised to forbear forever. Hobart, C.J., thought it unilateral, but that the plaintiff had forborne sufficiently for acceptance; he said, "without express words he is not chargeable by promise." Similar contracts were held to be bilateral in Therne v. Fuller (1616) Cro. Jac. 396; Cowlin v. Cook (about 1626) Latch, I5I. That Mr. Justice Holmes is not unwilling to discover the implication of a promise on evidence that seems not any too strong, see Wheeler $v$. Klaholt (IgOI) 178 Mass. I4I ; Martin v. Meles (IgOI) I79 Mass. II4.

Where a promise is given by the offeror, with a proviso or condition attached, the fulfilment of which requires action by the offeree, not only is it frequently inferred that such action is the intended consideration for the promise but it is also inferred that the offeree has promised that the 
Suppose A writes to B, "I will pay you $\$ 5,000$ for Blackacre," and B replies, "I accept your offer." This seems to be bilateral, and it is too late for A to revoke. A clearly makes a promise to pay money; and, according to the ordinary understanding of mankind, he requests $B$ to make a return promise to convey the land. But if $A$ has asked an actual conveyance of Blackacre as the equivalent of his promise, there is no contract at all, and A may revoke.

In example (8) above, some courts have found in the words of the parties a promise by A to pay to B a year's salary and a return promise by $B$ to serve for a year. In such case the hiring is not at will, but for a year; and this despite the fact that there are no express promissory words of that sort. ${ }^{13}$

In example (6) above, it has often been held that the offeree may accept by mailing a letter containing a promise to supply the goods-an "acceptance of the order," and that a revocation after such acceptance is too late, even though the goods are not yet shipped. ${ }^{14}$ It must not be assumed too readily that an order for goods is an offer of a promise in return for title to the goods to be effected by the act of shipment or otherwise. The offeror frequently wishes a return promise, as the offeree understands. The language used may be elliptical, and understood to be so.

\section{EXPRESS, IMPLIED, AND TACIT CONTRACTS}

A brief definition of these terms will suffice here. An express contract is said to exist when the acts of the parties declaring their will and intention are spoken or written words. A tacit contract is any other kind, the acts of the parties being sufficient

action shall take place. Dunton v. Dunton (1892) I8 Vict. L. R. II4; Jamieson v. Renwick (I89I) I7 Vict. L. R. I24; Lewis v. Atlas Mut. Life Ins. Co. (1876) 6r Mo. 534; cf. Binnington v. Wallis (1821) 4 B. \& Ald. 650.

On the other hand, where the defendant had made a written promise to remain with the plaintiff for two years for the purpose of learning to be a dressmaker, the court refused to draw the inference of a promise by the defendant to serve or of a promise by the plaintiff to employ. Lees v. Whitcomb (1828) 5 Bing. 34, 2 M. \& P. 86.

${ }^{13}$ Beach v. Mullin (1870) 34 N. J. L. 343, 345; Grossman v. Schenker (r912) 206 N. Y. 466 . See Mechem, Agcncy (2d ed.) sec. 603.

14 Anterican Pub. Co. v. Walker (1901) 87 Mo. App. 503; Gordon Malting Co. v. Bartels Brewing Co. (I9I2) 206 N. Y. 541; Sanford v. Brozun Bros. Co. (1913) 208 N. Y. 90; Bauman v. McManus (1907) 75 Kan. 106. 
to express their intention but not consisting of words, either spoken or written. It can easily be seen that a tacit contract is also, in a broader sense, an express one. Words are often lame and halting things in performing their function of expressing thought. It is often true in fact that actions speak louder than words. The term implied contract is generally used to mean exactly the same as tacit contract. The intention of the parties is "implied" or inferred from their actions other than words. For some centuries, however, it has been customary to describe as a "contract implied in law" certain other legal relations, in cases where neither the words of the parties nor their other acts justify an inference that they intended to create such relations. This usage seems to have been due to two reasons: in the earlier cases the courts desired to make the form of action called assumpsit available for the enforcement of certain duties not intentionally assumed; and in some of the later cases the courts desired to avoid the appearance of creating legal rights and duties where the parties had not so agreed. Thus the term implied contract became a slippery one upon which judicial reasoning has not infrequently slipped into error. The legal relations commonly described as contracts implied in law are now coming to be called quasi contracts. It is not necessary here to describe what these are; it is enough to observe that they are not contracts in fact, either express or tacit.

VOID, VOIDABLE, AND UNENFORCIBLE CONTRACTS

The term void contract is an apparent self-contradiction. This depends, however, upon the sense in which we are using the term contract. In this case it appears to be used to refer to the acts of offer and acceptance by the parties or to the document evidencing such acts.

In the case of a void contract, the parties perform acts that would usually operate to create new contractual relations, but have no such operation in the particular case. Rights and other relations will exist after such a transaction, but they will not be contract rights and relations. A contract right is a primary right in personam arising from expressions of consent. In the case of a void contract, there are expressions of agreement, but they do not have the usual legal effect. If these acts are mere words, they are not operative facts at all. Standing alone, they have no legal effect. They may, however, be accompanied by 
other acts, e. g., a delivery of goods, that have legal operation. The legal relations consequent upon these accompanying acts are never the ones that the parties had in contemplation. The offer creates no legal power in the offeree; and if his act of acceptance creates new legal relations, that is due to legal powers that he possessed even before the offer was made.

In the case of a voidable contract, the acts of the parties, even when they are mere words, operate to create new legal relations, and these are in a measure the ones contemplated by the parties. They are usually described as rights and duties, privileges and powers, etc., just as in the case of a valid contract $;^{15}$ but one of the parties has the additional power and privilege of extinguishing them. The exercise of this power is described as the disaffirmance or avoidance of the contract. Another way of describing a voidable contract is to say that the contemplated contractual relations do not yet exist, but that one of the parties has an irrevocable power to create them. His subsequent act is then called ratification.

The term unenforcible contract includes both void contracts and voidable contracts. It is customarily used so as to describe certain other legal relations also. When a contract has become unenforcible by virtue of the statute of limitations, the obligor or debtor has a power to create a new right in the other party as against himself (and to destroy his own existing privilege) by a mere expression of his will, without any act of assent by the other and without a new consideration. He cannot, however, as in a voidable contract, destroy the existing rights of the other party or create new rights in himself as against that other. When a contract is unenforcible by reason of the statute of frauds, either party has the legal power to create rights as against himself (or to terminate his existing power of destroying the other's rights) by signing a written memorandum, but he has no such power to create rights in his own favor. In these cases a legal relation exists that is different from that existing in the case of a void contract or of a voidable one.

15 "It was resolved that in all cases when the deed is voidable, and so remains at the time of the pleading (as if an infant seals and delivers a deed, or a man of full age by duress) in these and the like cases, the obligor cannot plead non est factum, for it is his deed at the time of the action brought." Whelpdale's Case (1605) 5 Coke, 119 a; Wald's Pollock, Contracts (3d ed.) p. 7 ; Windscheid, Pandekten, I, secs. 70, 82. 
It appears that this difference is not as one author says, "mainly a difference between substance and procedure." 16 The difference between a power to create a right against another person and a power to create a right against only oneself is not merely procedural.

Both voidable and unenforcible contracts are like valid contracts in this: there have been acts expressing agreement, and they are legally operative facts creating new legal relations. The resulting legal relations are different from those existing in the case of a valid contract; but these relations are distinct in character, are of considerable practical importance, and deserve even better names than they have received.

There are next to be considered the acts of offer and acceptance by means of which the foregoing legal relations are finally established, and also some of the intermediate relations that arise prior to the closing of the contract.

\section{THE OFFER}

Definition. An offer is defined above as an act whereby one person confers upon another the power to create contractual relations between them. It has not been customary to describe as a "power" the new legal relation consequent upon an offer ;17 but this term seems to be the most accurate description of that relation. It is similar to the relation existing in the case of agency. ${ }^{18}$ The principal, by an act called "appointment," creates in the agent the power of creating (in conjunction with a third person) new legal relations between the principal and a third person. After the one voluntary act of the principal called "appointment," nothing further remains to be done by him; thereafter it is the voluntary act of the agent that is operative to create new relations. So in the case of an offer: the act of the offeror operates to create in the offeree a power, and having so operated it is exhausted; thereafter the voluntary act of

\footnotetext{
16 Anson, Contracts (2d Am. ed., Huffcut) sec. 19.

17 The first, and the best, presentation of this concept that has been seen by the writer is in the article on Some Fundamental Legal Conceptions as Applied in Judicial Reasoning, in 23 Yale LAw Journal, 16, 49, by Professor W. N. Hohfeld, to whom the writer acknowledges great indebtedness. In Jordan v. Dobbins (1877) I22 Mass. 168, the court speaks of a continuing guaranty as "a power or authority which he might at any time revoke."

18 See Hohfeld, loc. cit. p. 46.
} 
the offeree alone will operate to create the new relations called a contract.

The Operative Act. What kind of act creates a power of acceptance and is therefore an offer? It must be an expression of will or intention. It must be an act that leads the offeree reasonably to believe that a power to create a contract is conferred upon him. This applies to the content of the power as well as to the fact of its existence. It is on this ground that we must exclude invitations to deal or acts of mere preliminary negotiation, and acts evidently done in jest or without intent to create legal relations. All these are acts that do not lead others reasonably to believe that they are empowered "to close the contract." So long as it is reasonably apparent that some further act of the offeror is necessary, the offeree has no power to create contractual relations by an act of his own and there is as yet no offer.

Communication. No act can induce another to believe that he is empowered to accept unless he is aware that the act has been performed. So it would seem to be essential that an offer shall be communicated to the offeree, and it has generally been held that acceptance is impossible prior to such communication. Thus, where a reward was offered by publication, for service desired, it has been held that the rendition of the service in ignorance of the offer creates no contract. ${ }^{19}$ The contrary has been held in some cases. ${ }^{20}$ Some judges have thought that where two offers, identical in terms, cross each other in the mail, there is no contract. $^{21}$ In these two instances there is no contract if the only way to create a contract is by the machine 1 y of offer and acceptance, regarded as acts expressing consent. In the reward cases, the offeror has acted and has consented; the offeree has acted but his act was not an expression of consent. In the case of crossed offers; each party has acted and has expressed consent;

19 Fitch v. Snedaker (1868) 38 N. Y. 248; Vitty v. Eley (I900) 5I App. Div. (N. Y.) 44; Williams v. West. Chi. St. Ry. (rgor) 19r Ill. 6 ro.

${ }^{20}$ Gibbons v. Proctor (I89I) 64 L. T. (N. S.) 594; disapproved by Pollock, Contracts (3d ed.) p. 2r; also by Anson, Contracts (2d. Am. ed., Huffcut) p. 25; also by Ashley, Contracts, p. 15. Smith v. State (1915) I51 Pac. (Nev.) 512; Dawkins v. Sappington (1866) 26 Ind. 199; Stone v. Dysert (1878) 20 Kan. 123; Cummings v. Gann (1866) $52 \mathrm{~Pa}$. St. $484 ;$ Neville v. Kelly (1862) i2 C. B. (N. S.) 740.

${ }_{21}$ Tinn z. Hoffman (I873) 29 L. T. (N. S.) $27 \mathrm{I}$; two judges contra. 
but in so doing, neither has knowingly exercised a power conferred by the other and neither has been induced to believe that he has such a power to exercise. Each has done an act conferring a power upon the other, and either one may now exercise that power by a subsequent act and thus create a contract. There is, however, no inevitable necessity in our adoption of the machinery of offer and acceptance. The rules of contract, like all other rules of law, are based upon mere matters of policy, or belief as to policy. In the process of our evolution we find that some or all of us are following a customary rule. When we become conscious of this fact, we try to express the rule in words and to compel others to obey it by legislative command. We may fail in our attempt, either because the custom supposed is not the custom of the powerful, or because we have failed to express it with accuracy, or because new life conditions require new customs. So, therefore, we may decree that two acts expressing consent, as in the case of crossed offers, shall create contractual relations; or that where an offer has been published, that act empowers others to create contractual relations by doing the acts requested, even though without knowledge of the request. It seems not improbable to the writer that this latter rule will prevail in the future. ${ }^{22}$ In the vast majority of cases, however, contracts will be made by offer and acceptance as analyzed above.

Time Limit. An offer having been made and a power having been thereby created, how long will this power continue to exist? The offeror is the creator of the power, and before it leaves his hands he may fashion it to his will. Such is the present decree of society. If he names a specific period for its existence, the offeree can accept only during this period. If the offeror names no period whatever, the power will be held to exist for a reasonable time, to be determined as a fact by the court and dependent upon the circumstances. ${ }^{23}$ If the parties are negotiating in each other's presence, the reasonable time will usually be a very short one; but if the offeror indicates that the power of acceptance is to be exercised in absentia, the reasonable time will be

22 This is the rule in fact adopted by the German Civil Code, sec. 657 . Ashley, Contracts, p. 13, says: "An offer uncommunicated is inconceivable." For cases where it was in fact conceived, see note 20 , supra.

${ }^{23}$ Loring v. Boston (1844) 7 Met. (Mass.) 409; Averill v. Hedge (1838) I2 Conn. 424 
considerably longer. ${ }^{24}$ If the time taken by the offeree would appear to be reasonable to a reasonably prudent man in his position, the acceptance is operative even though the offeror did not intend the power to exist for so long a period. A reasonable time may be longer than the offeror in fact intended. On the other hand, there seems to be no good reason for holding that the power of acceptance has expired if it can be shown as a fact that the offeror intended that it should still exist. A reasonable time may be longer than the offeror intended, but it can never be less. ${ }^{25}$

Revocation. In most cases the offeror may terminate the power of acceptance prior to the end of the specified period, if any, or of the reasonable time. In the first place he may have expressly provided that the power should be subject to revocation, either by notice to the offeree or without such notice. If he provides for a revocation without notice and by a mere change of his mental state, he can scarcely be said to have conferred any power at all. The power conferred by such an offer is a very flimsy one indeed, for the validity of the acceptance will depend upon the offeror's own will when he is notified of the acceptance. Such an offer is little more, in effect, than an invitation for bids. If the reserved power of revocation is to be exercised by an overt act, then there is a substantial power of acceptance, the validity of the act of acceptance being then not dependent upon the will of the offeror.

Even though the power to revoke has not been expressly reserved by the offeror, it can be said that as a general rule he retains such a power. In such a case, however, the power to revoke can be exercised only in a particular manner. If the offer was made by publication, it has been held that it can be revoked either by actual notice to a claimant or by a notice published in the same manner as was the offer. ${ }^{26}$ If the offer

\footnotetext{
${ }^{24}$ The German Civil Code, sec. 147, lays down substantially the same rule.

25 All that would seem to be necessary is overt action by the offeror sufficiently indicating his intention that the power shall continue. This principle is involved in the facts of Mactier $v$. Frith (1830) 6 Wend. (N. Y.) 103; Tinn v. Hoffman (1873) 29 L. T. (N. S.) 271. See criticisms of Mactier v. Frith, in Langdell, Summary of Cont., sec. 14, and Ashley, Contracts, p. 48.

${ }^{26}$ Shucy v. U. S. (1875) 92 U. S. 73; Pollock says of this case: "it seems a rather strong piece of judicial legislation." Wald's Pollock, Contracts ( $3 \mathrm{~d}$ ed.) p. 23 . To the writer it seems no stronger than are
} 
was made by personal communication to one or more particular persons, it can be revoked only by giving notice to them, such notice being effective only when received. ${ }^{27}$

Irrevocable Offers. It has been asserted that no offer can be irrevocable, ${ }^{28}$ various reasons being advanced for such a conclusion. It may be that by the prevailing rule of the common law offers are always revocable; it may even be true that considerations of policy and convenience require that all offers shall be revocable; but it is here insisted that the question of their revocability is not to be determined by rules of pure logic or of mathematics, that there is no inevitable necessity or universal law foreclosing discussion. The principle here to be adopted

the decisions on any other rule of the law. See also Sears $v$. Eastern $R$. Co. (I867) I4 Allen (Mass.) 433. The same rule is adopted by the German Civil Code, sec. 658 , and by the Jap. Civil Code, art. 530.

${ }^{27}$ Byrne v. Van Tienhoven (1880) 5 C. P. D. 344 ; Stevenson v. McLean (I880) 5 Q. B. D. 346 . See also Dickinson v. Dodds (I876) 2 Ch. D. 463 ; Frank v. Stratford (1904) I3 Wyo. 37.

In the early case of Hurford $v$. Pile (16I5) Cro. Jac. 483, an offer seems to have been held to be irrevocable. The entire report is as follows :

Assumpsit. Whereas J. S. being in execution for forty pounds, the defendant said, "Deliver J. S. out of execution, and what it cost you I will repay ;" wherefore J. S. was discharged by the plaintiff. The defendant for plea saith, that after the assumpsit, and before the plaintiff had done any thing in that business, he forbade him to meddle therein, and that he would not stand to his promise. The plaintiff demurred; and it was adjudged for the plaintiff.

Houghton, Justice, said, that a man may discharge an assumpsit made to himself, but he cannot discharge an assumpsit made by himself: but, at another day, the defendant's counsel moved, that it was a good plea, and that as long as nothing was done, it was but an executory promise.

Doderidge. If I promise to J. S. that if he build an house upon my land before Michaelmas, I will pay him a hundred pounds, and I countermand it before he hath done any thing concerning the house, it is a good countermand.

Houghton è contra; but he said, that may be considered in damages adjournatur.

Afterwards, in Trinity term, judgment was given for the plaintiff.

See also Hoze v. Beeche (1685) 3 Lev. 244.

28 "It is indispensable to the making of a contract that the wills of the contracting parties do, in legal contemplation, concur at the moment of making it. An offer, therefore, which the party making it has no power to revoke, is a legal impossibility." Langdell. Summary of the Law of Contracts, sec. 178, also sec. 4. See also, Wormser, The True Conception of Unilateral Contracts, 26 Yale Law Journat, 137, note; Lee, Contract, Jenks, Digest of Eng. Civ. Laze, sec. 195; Ashley, Contracts, sec. 13. 
is of the same character as any other legal principle, and is to be determined by established custom, by positive legislation, and by considerations of policy and convenience. ${ }^{29}$ In various systems of law in other countries, and sometimes by statute in this country, offers are expressly declared to be irrevocable under certain circumstances. ${ }^{30}$ These statutes, however, might be construed as depriving the offeror of his privilege of revoking without depriving him of his pozer to revoke. It is not believed that they would be so construed. The view that an offer cannot be irrevocable seems based upon a failure to bear in mind the essential character of the relation as a power conferred upon the offeree. If an offer were a physical emanation, a sort of radioactivity of a human body, no doubt a stop might always be put to it. If an offer were a state of mind, no doubt society could not ordain its continuance against the offeror's will. ${ }^{31}$ An offer, however, is an act creating the legal relation called a power to accept. The act cannot be revoked at all, for it is of yesterday. The resulting power is from society and can be maintained by society indefinitely. ${ }^{32}$

${ }^{29}$ Langdell seemed to regard considerations of this sort as "irrelevant." See Summary of the Law of Contracts, sec. I5.

${ }^{30}$ Swiss Code of Obligations, sec. 3: "One who makes an offer to another, and prescribes a definite time for acceptance, is bound by his offer until the expiration of the time fixed."

German Civil Code, sec. 145: "One who has conferred upon another the power to close a contract is bound by his offer unless he has provided to the contrary." (But the Code provides that if no time is specified, the acceptance must take place within a brief period according to circumstances. See secs. 147-I50.) Sec. 658: "An offer of a reward is revocable prior to the beginning of performance."

Japanese Civil Code, art. 52I: "An offer of a contract made with a fixed period of time specified for acceptance cannot be withdrawn." Art. 524: "An offer made to a person at a distance without fixing a period of time for acceptance thereof, cannot be withdrawn for such a period of time as is reasonably necessary for the offeror to receive notice of the acceptance."

By sec. 3645 , Civil Code of Georgia, it is provided that a "party may withdraw his bid or proposition, unless a given time is agreed on in which the other party may assent." See Black v. Maddox (1898) ro4 Ga. 157, 16r.

31 This was perhaps Langdell's view, although he often uses expressions inconsistent with it; and it is maintained in Ashley, Contracts, sec. 13.

${ }^{32}$ In Adams v. Lindsell (1818) I B. \& Ald. 68I, it was said: "The defendants must be considered in laze as making, during every instant of the time their letter was travelling, the same identical offer to the plain- 
Physical Limitation. Irrevocability may have any one of several meanings: first, that the offeror has no legal power to revoke by any means, lawful or unlawful; second, that he is not legally privileged to revoke, although he may have the legal power; third, that although he has both the legal power and the privilege of revoking by certain means, these means are not within his present physical capacity. Under our law nearly all offers are for a time irrevocable in the third sense. Revocation can take place only after a certain fashion, commonly by giving actual notice to the offeree. So long as it is impossible to reach the offeree with such a notice or to do such other act as may amount to a revocation, the power of acceptance will continue to exist.ss This means that although the offeror is privileged to revoke and has the legal power to revoke by doing certain acts, the performance of these acts is beyond his limited human capacity.

Contractual Limitation. An offeree's power is irrevocable in the second sense, either by the giving of notice or otherwise, if the offer is put in the form of a conditional covenant or simple contract, ${ }^{34}$ or if the offer is accompanied by a promise not to

tiffs." See also Boston and Maine R. Co. v. Bartlett (1849) 3 Cush. (Mass.) 224; Nyulasy v. Rowan (I89I) I7 Vict. L. R. 663. If an offer were at every instant revocable, these decisions would be wrong, and Cooke v. Oxley (1790) 3 T. R. 653 would not have been overthrown.

33 See Ashley, Contracts, p. 34.

34 O'Bricu v. Boland ( 1896 ) I66 Mass. 48I; Watkins v. Robertson (1906) I05 Va. 269; Dambmann v. Rittler (I889) 70 Md. 380; McMillan v. Ames (1885) 33 Minn. 257. Some cases refuse specific performance, if revocation preceded acceptance, but expressly on the ground of lack of consideration, and they indicate that the offer is irrevocable if a consideration is paid. Corbett v. Cronkhite (Ig09) 239 Ill. 9; Crandall v. Willig (1897) I65 Ill. 233; Graybill v. Bruyh (1893) 89 Va. 895; Bishop Contracts, sec. 325. In I Ames, Cases on Equity, p. 200, is the following note: "if after giving an option to buy certain property the giver makes a will devising the specific property, the courts, to effectuate the supposed intention of the testator, give to the devisee the land, if the option is not exercised, and the proceeds, if the holder of the option elects to buy. Drant v. Vause (1842) I Y. \& Coll. 580; Emuss v. Smith (1848) 2 De G. \& Sm. 722; In re Isaacs [1894] 3 Ch. 506, 510; In re Pyle [1895] I Ch. 724." The devise is an apparent act of revocation, but a subsequent acceptance is effective, and the acceptor is entitled to specific performance.

Butler and Baker's Case (I59I) 3 Coke, 25 a, 26 b, presents a good illustration of an irrevocable power: "If $\mathrm{A}$ makes an obligation to $\mathrm{B}$ and delivers it to $C$ to the use of $B$, this is the deed of $A$ presently; but if $C$ offers it to $B$, there $B$ may refuse it in pais, and thereby the obligation will lose its force." This is a covenant, delivered in escrow, con- 
revoke given for a consideration or under seal. In such case the offeror is never privileged to revoke, and he may not even have the legal power. It may be said that these are contracts and are not mere offers; but the fact remains that in all such cases the act of the offeror has conferred upon the offeree a power to create future relations, a power that is in all respects similar to the power conferred by any offer, a power to be exercised by the voluntary act of the offeree alone. The offeree is not bound to do the act that constitutes the condition or acceptance; but if he does do that act, new contractual relations are created. When the courts enforce the duties included among these relations, they do so expressly on the theory that there was an offer that could not be revoked. ${ }^{35}$

ditional only upon B's assent. A has no power of revocation, as is universally held. It is due to the fact that B's power is irrevocable that the courts have called the existing relations a contract, a tendency noticeable in other cases. See notes $4 \mathrm{I}$ to 47 , below. Some will maintain that in this case B has a right; but if so, he also has the power to destroy it by a mere expression of dissent, and this cannot be said of contract rights in general.

35 In O'Brien v. Boland, supra, the court said: "In the present case, because the offer was under seal, it was an irrevocable covenant, conditional upon acceptance within ten days, and the written acceptance within that time made it a mutual contract which the plaintiff can enforce." In Guyer v. Warren ( 1898 ) I75 I1l. 328 , it is said: "The covenant in the present contract, giving an option to purchase, was in the nature of a continuing offer to sell." In Willard $v$. Tayloe (1869) 8 Wall (U. S.) 557, Justice Field said: "The covenant in the lease giving the right or option to purchase the premises was in the nature of a continuing offer to sell. It was a proposition . . . . from which the defendant was not at liberty to recede."

On the other hand, in Mansficld $v$. Hodgdon (1888) 147 Mass. 304, Mr. Justice Holmes said: "The defendant's undertaking not having been a mere offer, but a conditional covenant to sell, bound him irrevocably to sell in case the plaintiff should elect to buy."

In Galton v. Emuss (1844) I Coll. 243, one Nash contracted with Galton that he should "have the offer, for twelve months, of both the estates . . . . by the trustees under the will of the said John Nash." Later Nash devised the estates to the trustees, defendants, for other uses and with no power to convey to the plaintiff. The trustees refused to offer the estates to the plaintiff on the agreed terms, but the plaintiff gave them notice of this intention to purchase. Vice Chancellor Knight Bruce decreed specific performance.

In Jordan v. Dobbins (1877) I22 Mass. I68, a conditional covenant was held to be revocable. 
If there is in fact a promise to keep the offer open for a specified time, the question of revocation should turn upon the matter of consideration and upon the question of damages. If there is an agreed equivalent given for the promise, a repudiation will beyond doubt create a right to damages. The same result would be reached where the offeree has done detrimental acts in reasonable reliance upon the promsie in those courts adopting the (so-called) estoppel theory of consideration. ${ }^{36}$ Further, in this case the offer should be held to be irrevocable and the repudiation of the promise to be wholly without the effect intended, if a subsequent acceptance does not unreasonably increase the damages to be suffered by reason of the breach. In this case, the offer would be irrevocable in the first (and the best) sense. After a contract has been made, a repudiation by one of the parties creates in the other only a right to such damages as he will suffer after taking all reasonable steps for the prevention of damage. If further performance by him will increase his loss, the other party is under no duty to pay the damages caused by such further performance. ${ }^{37}$ But if such action will not increase his loss, he may proceed with his performance without affecting his claim to damages. In the cases now being considered, whether they be regarded as contracts to hold an offer open or as conditional covenants, the power conferred should be regarded as irrevocable if the execution of the power does not increase the damage to be suffered in case of breach. Such damages are not increased in any respect if the act of acceptance or the fulfilment of the condition consists merely in the giving of a notice or the making of a promise. In spite of an attempted revocation, the offeree still has the power of acceptance; while the offeror lacks not only the privilege of revoking, but also the power to revoke. Thus, suppose that A should offer to convey Blackacre in return for B's promise to pay a price named, and should promise for a consideration or under seal not to withdraw the offer for 30 days. In such a case, acceptance (the act of exercising the power) would be merely the making of a promise to pay the price. This would

${ }^{36}$ See Clarno v. Grayson (I896) 30 Or. III. The Illinois Court refused to hold that such a reliance made the offer irrevocable. Corbett $v$. Cronkhite (I909) 239 Ill. 9.

37 Clark v. Marsiglia (I845) I Den. (N. Y.) 3I7; American Pub. Co. v. Walker (I90I) 87 Mo. App. 503 . 
not in any respect increase the damage suffered by reason of a breach. B's damages, whether for breach of the preliminary option contract, or for breach of the subsequently created contract to convey, would be the value of Blackacre, less the contract price. In cases where B's damage is regarded as irreparable, he should be given a decree for specific performance in equity. The same conclusion follows if the transaction be regarded as a covenant to convey Blackacre on condition that a promise by $\mathrm{B}$ to pay the price shall be made within 30 days. ${ }^{38}$

Suppose, however, that A offers to pay $\$ 5,000$ to B in return for the destruction by $B$ of a valuable building that obstructs A's view, giving $B$ a 30-day option as before. If in this case A gives notice of repudiation, B's power of acceptance (or of creating new contractual relations by fulfilment of the condition) is destroyed. The act of acceptance is here a very expensive one and would greatly increase the loss. B cannot maintain an action of debt for $\$ 5,000$, for the destruction of the building was the quid pro quo and its fulfilment would now be unjustifiable. B's remedy is in assumpsit for damages, being $\$ 5,000$, less the value of the building saved. Even in a case of this sort, if A has promised to convey Blackacre, instead of to pay money, and the breach of his promise is regarded as about to cause $B$ irreparable injury, equity would no doubt approve the destruction of the building and would decree specific performance of A's promise. In such a case, A's offer is clearly irrevocable, in the true meaning of that term.

Specific Performance. An obstacle to specific performance in equity may be supposed to exist in case the option (let us suppose an option to buy) is a contract to hold an offer open instead of a conditional covenant or simple contract. In the latter case there is a completed obligation to convey, and this may be enforced. In the former case there is no such obligation, and none can be made because the option contract has been broken and the offer has been revoked. This obstacle can be avoided by the simple expedient of not seeing it. The asserted impossibility of doing an act has many a time been disproved by doing it. If by definition the thing is impossible, change the definition. The objection can be met verbally in two ways: first, by the easy method of declaring the offer irrevocable and the

${ }^{38}$ Black v. Maddox (1898) I04 Ga. 157 ; and cases in note 34, supra. 
option contract unbreakable. ${ }^{39}$ That this can be done has already been shown above. There is nothing foreign to our law in the idea of an irrevocable power, and the legal relation resulting from an offer is a legal power. The power to accept being still alive, the offeree may exercise it and thus create the obligation to convey, all fit and ready for specific enforcement. The second form of meeting the objection may be preferred by some, but it is the same in essence. Everybody agrees that the option contract creates an obligation that is enforcible. It may be described as a contract to make a contract. Even if the second contract-the obligation to convey-is never formed, equity still has jurisdiction on the ground that money damages are inadequate. Nor is it without the power to enforce a decree. Even if we suppose that equity cannot specifically enforce the contract to make a contract, it can do exactly what it does in all of its decrees for specific performance: it can decree specific reparation. In this case a conveyance of the property would be such reparation, for it was the ultimate object of the option contract. Nobody doubts the power of equity to force a conveyance of the res and to compel the creation of new rights in rem, even though many have supposed that this can be done only by acting in personam. ${ }^{40}$ Indeed, it seems strange that these same individuals should doubt the power of equity to compel the creation of a new obligation in personam, through the medium of an irrevocable power.

Limitations Due to Part Performance. There are still other cases where it has sometimes been held that an offer is irrevocable, even though there is no express promise to hold the offer open. These are offers made in such terms that they can be accepted only by performing a series of acts requiring an appreciable length of time and effort or expense. Upon complete performance of these acts, the power of acceptance becomes irrevocable because it has been fully executed and a contract has resulted; but in a few cases it has been held, contrary to what is generally supposed to be the rule, that the offer becomes irrevocable after the offeree has begun to perform the requested acts of acceptance

${ }^{30}$ Langdell said that a contract incapable of being broken "is also a legal impossibility;" Summary of Cont., sec. I78. He rested his statement, however, upon the premise that no offer could be irrevocable.

40 For an elucidation of this point see the excellent article on The Powers of Courts of Equity, in 15 CoL. L. REv. 37, 106, 228, by Professor Walter Wheeler Cook of the Yale School of Law. 
or has performed a substantial part of such acts. ${ }^{41}$ It must be observed that after such a part performance there is as yet no contract, for by hypothesis acceptance was to consist of complete performance. If the offer has become irrevocable, however, the offeree still has the power to create a contract by completing the requested acts, in spite of a notice to the contrary from the offeror. The principle applied in these cases is applicable not merely to offers of unilateral contracts, but also to offers where the offeree is requested to make a return promise and to express it by one or more acts requiring a considerable expenditure of time or money. The cases in point, however, are mostly cases of offers to make a unilateral contract.

In one case, the defendant offered a reward for the arrest and conviction of some criminals. The plaintiff arrested them and induced their confession, but they were not convicted because the defendant wished to use their testimony in other cases and so had the indictments dismissed. It was held that the plaintiff was entitled to the reward.42

Again, a defendant delivered a negotiable note in escrow for the plaintiff, to be paid when the plaintiff had completed a line of railway. After part performance by the plaintiff the defendant gave notice of revocation. The court held this notice to be ineffective, saying: "it would be manifestly unjust thereafter to permit the offer that had been made to be withdrawn. The promised consideration had been partly performed, and the contract had taken on a bilateral character." ${ }^{, 33}$

41 Hozve v. Beeche (1685) 3 Lev. 244; Dambnamu v. Rittler (1889) 70 Md. 380 , may be such a case, although the court treats the case as if there were a conditional contract to deliver at the buyer's option. The court states a promise by defendant to deliver from 300 to 500 tons of phosphate, the plaintiffs to give 24 hours' notice of their wants. No promise by the plaintiff, or other consideration, is stated. After 300 tons had been delivered, the defendants repudiated further obligation; but the court held the defendants bound to fill later orders. See following notes.

${ }^{42}$ Louisville \& N. R. Co. v. Goodnight (1874) Io Bush (Ky.) 552. Similar cases are: Stone v. Dysert (1878) 20 Kan. 123; Stephens v. Brooks (1867) 2 Bush (Ky.) I37; Mosley v. Stone (1900) I08 Ky. 492; Willians v. U.S. (1876) 12 Ct. Cl. 192. Contra, Biggers v. Owen (1887) $79 \mathrm{Ga} .658$.

13 Los Angeles Traction Co. v. Wilshire (1902) 135 Cal. 654; if the note can be regarded as a specialty, the decision is supported by the principle of Butler and Baker's Case, supra, note 34 ; cf. Gray v. Hinton (I88I) 7 Fed. 81. 
In another case, a corporation passed a by-law providing that employees should be entitled to a share in the profits after serving for a named period. The plaintiff was discharged one day before he would have been entitled to share under this by-law. His action for such share was sustained, the court saying: "It is true as a general proposition that a party making an offer of a reward may withdraw it before it is accepted. But persons offering rewards must be held to the exercise of good faith and cannot arbitrarily withdraw their offers for the purpose of defeating payment." $\$ 4$

A defendant offered to buy all railroad ties "you put on at Gap within the next twelve months." The plaintiff had supplied I,000 ties and had secured material for 5,000 more, when the defendant gave notice of revocation. The court held the plaintiff to be entitled to damages for failure to take the remaining 5,000 ties. ${ }^{45}$

If an owner has offered a commission to a real estate broker, to be earned by effecting a sale, can the offer be revoked after the broker has spent time and money and may have a sale nearly consummated? In such a case the courts are very ready to make the assumption that there was a bilateral contract, for breach of which the broker is entitled to damages, or that the services of the broker were completed, the acceptance valid, and the reward earned. ${ }^{46}$

Suppose a prize is offered to the winner of a race or to the winner of a voting or guessing contest, under specified rules; can the rules be changed or the offer be withdrawn by the offeror, after substantial acts in reliance thereon by contestants? There

\footnotetext{
14 Zrolanek v. Baker Mfg. Co. (I912) I50 Wis. 517.

${ }_{45}$ Louisville \& N. R. Co.v. Coyle (1906) 123 Ky. 854; cf. Rehm-Zeiher Co. v. Walker (1913) $156 \mathrm{Ky} .6$.

18 See Blumenthal v. Goodall (18gr) 89 Cal. 25I. Where a definite time was fixed for the making of the sale, the broker cannot earn his reward by completing the service after the time. Zeimer v. Antisell (1888) 75 Cal. 509. If the offer has been held open for a reasonable time, and the broker has failed to render the service after a definite attempt, the offer has been said to be revocable if the defendant is acting "in good faith." See Sibbald v. Bethlehem Iron Co. (I88r) 83 N. Y. 378 ; Cadigan $v$. Crabtree (1904) 186 Mass. 7; Livery v. Miller (1883) 6r Md. 337. The inference may be drawn from these cases that a revocation made unreasonably or "in bad faith" would be ineffective.
} 
are cases tending to justify an inference, though not deciding, that the offer has become irrevocable. ${ }^{47}$

Where a reward has been offered for the return of a lost article, it has been held that the finder has a lien on the article to compel payment of the reward, without stopping to consider whether or not the reward has been earned before delivery. ${ }^{47 a}$ It is apparent that the offer has become irrevocable before delivery.

The rule that offers like the foregoing are revocable at any time prior to complete performance of the acts requested has encountered some criticism. ${ }^{48}$ Sometimes a court is astute to find that in fact there was no revocation. ${ }^{40}$ In many instances the existence of a bilateral contract has been assumed without close analysis of the facts, in order to render a revocation ineffective. ${ }^{50}$

47 Mooney v. Daily Nezus Co. (I9II) II6 Minn. 212; Minton v. Smith Piano Co. (IgII) 36 App. Cas. (D. C.) 137,33 L. R. A. (N. S.) 305.

4ia Wood v. Pierson (188I) 45 Mich. 313; Wentworth v. Day (184I) 3 Met. (Mass.) 352; Wilson v. Guyton (I849) 8 Gill (Md) 213, semble; see also Cummings v. Gann (1866) $52 \mathrm{~Pa}$. St. 484.

48 Wald's Pollock, Contracts (3d ed.) p. 34, note ("the result is harsh") ; Wharton, Contracts, sec. I3; W. W. Story, Contracts (5th ed.) sec. 495.

49 See Quick v. Wheeler (1879) 78 N. Y. 300.

50 There are numerous option contracts where the acceptance prescribed would seem to be payment or some other onerous performance, but the court has held that a mere notice of acceptance is sufficient to create a bilateral contract. See Murphy Thompson v. Reid (1907) $125 \mathrm{Ky} .585$; Rockland-R. Lime Co. v. Leary (IgII) 203 N. Y. 469; Barrett v. McAllister ( 1890$) 33$ W. Va. 738; article on Option Contracts by the writer in 23 Yale LAw Journal, 64r. See also the argument in Offord $v$. Davies (1862) 12 C. B. (N. S.) 748. Sir Frederick Pollock, reviewing Ashley on Contracts in 28 LAW QUART. Rev. I00, says: "If this be so (that there is no acceptance until the act is completed), the promisor may withdraw his offer when the work is all but done, or the promisee may capriciously leave the work half done, and in either case without remedy, unless there be something in the circumstances which can be made to support an action of tort. A carter, for example, who is carrying goods to a wharf to be put on an outgoing ship, may abandon them in the middle of the journey. Both the plain man and the average lawyer will say that, whatever Prof. Ashley's logic may be, the law really cannot be so absurd as that; and they will be right, and, what is more, any rational court before whom such a question is moved will surely find a way to make them so. It might easily be held that acting on a request for an act to be done for reward implies a promise to go through with the performance. At all events it seems to us that the offer is irrevocably accepted by the first unequivocal commencement of the act requested. In fact it does not 
It is often maintained that the offer is irrevocable after the offeree has done an act that binds him to complete the requested performance. ${ }^{51}$

It has been suggested that in cases of the above sort, even in the absence of an express promise not to revoke an offer, a promise not to revoke is implied, the consideration therefor being any substantial act whereby the requested performance is begun. ${ }^{52}$ If such an option contract is justly inferable in fact, it is governed by the same rules as an express contract to keep an offer open. This has been discussed above. In many instances, however, the inference of such a promise would be contrary to fact. In those cases the promise would be a fiction and the agreement that the beginning of performance should be the consideration for this promise would likewise be a fiction. The purpose of such a fiction is to make the offer irrevocable and it is based upon a belief as to policy and general advantage. If this is true and if in our process of evolution we have become conscious of the fact, we are ready to discard the fiction and to express in appropriate words the rule and its reason. It might be expressed somewhat like this: Where an offer has been made so that it can be accepted only by performing a series of acts requiring an appreciable length of time and effort or expense, such offer shall be irrevocable after the offeree has begun the performance of the requested acts, unless the offeror expressly reserved the power of revocation. ${ }^{53}$

often happen that a man sets about a job without writing or uttering some kind of word of acceptance. 'All right' is enough. Thus the practical outcome of Prof. Ashley's ingenious exercise may be to convince us that there are fewer unilateral contracts in the world than we supposed." See also Bronnenberg v. Coburn (1886) IIo Ind. I69, and cases in note I4, supra.

51 Morrow v. So. Express Co. (1897) ror Ga. 810; Plumb v. Campbell (1888) I29 Ill. IOI; I Parsons, Contracts (5th ed.) p. 45I. In Lascelles v. Clark (1910) 204 Mass. 362, the defendant offered a guaranty "in consideration of your continuing for the next month the account current between you . . . . and D." The plaintiff at once made an agreement with $\mathrm{D}$ for credit during the month. It was held that this completed the contract of guaranty. Assuming that if acceptance were to consist of acts covering the whole month the offer would be revocable on the 29 th day, the court says: "It cannot be supposed that the parties meant that." Gelpcke v. Quentell (1878) 74 N. Y. 599.

¿2 McGovney, Irrevocable Offers, 27 HARv. L. Rev. 654.

83 There is a similar provision in the German Civil Code, sec. 658. 
To this rule there should probably be added some such rule as the following: If the continuation of performanec will increase the amount of the offeree's claim, the revocation shall be effective; in such case if the offeree can show with reasonable certainty that he would have performed in full, he shall be entitled to the same damages as if the contract had been a bilateral contract in the beginning. ${ }^{54}$

Possible Unfairness. In this class of cases the question is of some complexity, and it cannot be said that the above rules represent the settled law of any jurisdiction. There is enough reason and authority in their favor, however, to warrant their careful consideration in new legislation, parliamentary or judicial. A possible argument against such rules is that they would operate unfairly and unequally as between offeror and offeree. The offeree will remain free to discontinue performance without any claim for damages arising against him, while the offeror will bear an irrevocable liability. The offeree remains legally privileged and empowered to prevent a contract; the offeror's privilege is wholly gone and in some cases his power of revocation is gone also. It has been our custom to say that both parties must be bound or neither is bound, but this properly applies only to transactions by which it is intended to creat bilateral duties. A closer consideration will show that there is no real unfairness on this score. The offeror is the one who invites action by the offeree, and he invites it in such a way that the offeree bears all the risk of loss. The offeror will have to pay nothing if the acceptance is not fully completed, and if it is so completed he has received the requested equivalent for his promise. The offeror has asked for no rights against the offeree and has invested nothing in the hope of such rights and has been induced to do expensive acts in reliance upon such expectation. The offeree may find eventually, after much labor and

54 A provision in some respects like this is contained in the Swiss Code of Obligations, sec. 8 .

s5 It is true that the acceptor's performance may confer rights in rem upon the offeror and he may have made investments in the hope of such rights. Also, as stated previously, the acts of the offeree may be the prescribed mode of expressing a promise, in which case the offeror hopes for a right in personam; this would be a rare case. It is not believed that these exceptional cases (for which a separate rule might be desirable) affect the validity of the argument above. 
expense, the complete acceptance by him is impossible or so expensive as to exceed the offered compensation. Complete acceptance may become impossible by reason of a third party's previous acceptance of the offer. From this it appears that it is fair enough for the one who bears the risk to possess the privilege, while the other, bearing no risk, is deprived of both privilege and power. ${ }^{50}$

Termination of Power by Offeree. The power created by an offer may be terminated not only by the offeror but also by the offeree, the possessor of the power. His mere failure to exercise the power will not in itself cause such a termination, except as such a failure fulfils a condition prescribed by the offeror or by the law. If the offeror has expressly limited the life of the power, he has thereby caused a failure to accept within the prescribed period to be an operative fact. If the power to accept is limited by the law to a "reasonable time," the law has caused failure to accept to be an operative fact. However, in such cases it would be more in accord with the instinct of the average man to designate the act of the offeror as the cause both of the birth of the power to accept and of its death.

It is usually said that the power of acceptance is terminated by the act of the offeree in definitely rejecting the offer or in making a conditional acceptance or counter offer. This is not necessarily true. The offeror is the creator of the power and he may cause it to live in spite of rejections and counter offers. If the offeror should make an offer and at the same time notify the offeree that the power to accept shall exist for two weeks and that a rejection or counter offer shall not terminate it, it can hardly be expected that a court would disregard the offeror's expressed intention. The offeree may still reasonably believe the offer to be open. The same result should follow, even in the absence of an express notice, if the offeror has done any other overt acts expressing such an intention. The real reason why a rejection or a counter offer should terminate the power to accept

${ }^{56}$ The reason for making an offer irrevocable given in deBecker's Annotated Civil Code of Japan, art. 521, is: "the offeror cannot freely withdraw his offer within the specified period of time, because the other party may require to make some preparations for accepting it, and if after he had made those preparations and was about to accept the offer, the offeror suddenly withdrew the offer, it might cause a great deal of prejudice and annoyance to the other party." 
seems to be the effect that they will probably have upon the thought and actions of the offeror. If in the particular case they have had no effects whatever-and the party asserting rights under a contract must be able to show this-it should be held that the power continues to exist. If, after a rejection or counter offer, the offeror has done no overt act prior to the subsequent act of acceptance, indicating with reasonable certainty that he intends the power still to exist, no doubt it would be held that such an acceptance has only the effect of a new offer; otherwise the acceptor would be wholly at the offeror's mercy, for the latter could prove the overt acts of acceptance, but the acceptor could not prove that the offeror had continued to hold the offer open. If the offeror has in fact done an overt act indicating his intention to continue the existence of the power, there seems to be no practical necessity for a notice of such act to be given to the offeree, except that without such a notice he may never accept. If without such a notice he does accept, he is still being induced to act by the original notice. $\mathrm{He}$ is acting in accordance with a power that he thinks he has, and that he has in fact. If he can prove the facts as against the offeror, the latter should be bound. The offeror will have no difficulty in proving the facts as against the offeree, for he has evidence of the acceptance and also of his own overt act continuing the power.

Revocation by Death or Insanity. The general rule is that the power of acceptance is terminated by the death or by the supervening insanity of either the offeror or the offeree. This rule also may be in harmony with the public interest; but there is not, as is often supposed, any compelling necessity for its existence. It may be said that you cannot contract with a dead man; but neither can you force a dead man to pay his debts contracted before his death. Yet the law has no difficulty, in the latter case, in creating legal relations with the dead man's personal representative, and there would be no greater difficulty in declaring the power of acceptance to survive as against the offeror's representative or in favor of the offeree's representative. ${ }^{57}$ It may again be suggested that an offer is not a physical sensation or a state of mind. Powers "coupled with an interest" survive the death

\footnotetext{
${ }^{67}$ The German Civil Code, sec. 153, provides that the death of the offeror shall not end the power, unless the contrary intention is apparent. See Ashley, Contracts, sec. 17, note 2.
} 
of the grantor of the power. This rule might well apply to offers where the acceptance is to consist of a series of acts requiring time and labor or expense, and part performance has taken place before notice of the death. It is on similar grounds that option contracts have been enforced, although the acceptance was subsequent to the death of one of the parties. ${ }^{58}$ It is generally held that the power created by a continuing guaranty is not destroyed by the death of the guarantor without knowledge thereof by the creditor. ${ }^{\mathrm{s} a \mathrm{a}}$

\section{ACCEPTANCE}

An acceptance is a voluntary act of the offeree whereby he exercises the power conferred upon him by the offer, and thereby creates the set of legal relations called a contract. ${ }^{59}$ What acts are sufficient to serve this purpose? We must look first to the terms in which the offer was expressed, either by words or by other conduct. The offeror is the creator of the power and at the time of its creation he has full control over both the fact of its existence and its terms. The offeror has, in the beginning, full power to determine the acts that are to constitute acceptance. After he has once created the power, he may lose his control over it, and may become disabled to change or to revoke it; but the fact that, in the beginning, the offeror has full control of the immediately succeeding relation called a power, is the characteristic that distinguishes contractual relations from non-contractual

${ }^{68}$ See In re Adams \& K. Vestry (I884) 27 Ch. D. 394; Ankeny v. Richardson (IgII) I87 Fed. 550; Dibbins v. Dibbins (I896) 2 Ch. 348; Tozunley v. Bedwell (1808) I4 Ves. 591; Lawes v. Bennett (1805) I Cox, 167; Nicholson v. Smith (1882) 22 Ch. D. 640; Rockland-R. Lime Co. v. Leary (IgII) 203 N. Y. 469.

s8a Bradbury v. Morgan (1862) I H. \& C. 249; Coulthart v. Clementson (I879) 5 Q. B. D. 42, semble; Harriss v. Farecett (I873) L. R. 8 Ch. 866, semble; In re Whelan [1897] I Ir. 575. Contra, Jordan v. Dobbins (1877) 122 Mass. I68. In Knotts v. Butler (1858) 1o Rich. Eq. (S. C.) I43, it was held that the guaranty was not terminated by death of the guarantor with knowledge thereof by the creditor. The great weight of authority is opposed to this.

${ }^{80}$ Sometimes the closing of the contract requires not merely acts of the acceptor, but also other operative facts-as where the offeror prescribes that no contract shall exist until he receives the letter of acceptance. With the mailing of the letter the acts of the offeree may come to an end; but the receipt of that letter is another necessary operative fact. See Lewis v. Browning (188I) I30 Mass. 173 . 
ones. After the offeror has created the power, the legal consequences thereof are out of his hands, and he may be brought into numerous consequential relations of which he did not dream, and to which he might not have consented. These later relations are nevertheless called contractual.

Silence. There is one limitation upon this power of the offeror. It has been held that he cannot confer a power of accepting by mere silence. ${ }^{60}$ In one aspect, this seems to be a not unreasonable limitation. The opposite rule, in such cases, would enable the offeree to await the event, and to deny the fact of acceptance if the contract now appears to be to his disadvantage, or to assert the fact of acceptance if appearances are to the contrary. This argument, however, proves too much; for it applies with equal force to any positive act that might reasonably be performed even though no offer has been made, and that has no more probative force to establish assent than to establish some other fact. Whether or not it would be so applied may be regarded as doubtful. ${ }^{01}$ A strong argument in favor of holding the acceptance good is that the offeror has only himself to blame if the terms of his offer put him at the mercy of the offeree, and that he should not be permitted to escape liability when he has induced the offeree to believe that there is a contract and to act in reliance thereon. The weight of these opposing arguments cannot be determined with certainty; but it will be a rare case where the offeree has not done some overt act which indicates his intention to accept, and in such case the courts would undoubtedly hold that the acceptance was good. This rule must not be confused with the one to the effect that the offeror cannot arbitrarily cause the silence or other ordinarily non-expressive act of the offeree to operate as an acceptance against the will of the offeree. ${ }^{62}$ The offeror may, perhaps, confer the power on the offeree to make such an act operate as an acceptance; but he cannot unreasonably deprive the offeree of his preëxisting immunity in doing those acts or of his power to make them operate otherwise. Thus, if the offeror declares that the offeree shall accept by remaining silent or by eating his breakfast, the offeree cannot be held against his will even though he seems to

${ }^{60}$ Prescott v. Jones (1898) 69 N. H. 305; Felthouse v. Bindley (1862) II C. B. (N. S.) 868; $c f$. also Kühn, Ueber Vertragsschluss unter Abwesenden, Ihering's JAHrbucher, (N. Folge) 4, p. 5 ff.

B1 See White v. Corlies (1871) 26 N. Y. 467.

62 Royal Ins. Co. v. Beatty (I888) IIg Pa. St. 6. 
comply with the terms of the offer. In such a case, the conduct of the offeree may with equal reason be regarded as an expression of quite different intentions and desires. In such case, it might be left to the jury to determine whether or not the act was done with the intention to accept ${ }^{e s}$; but it would be better to instruct the jury that there is a contract only if the conduct of the offeree has reasonably led the offeror to believe there has been an acceptance. ${ }^{64}$

Impossible Acts. Since the offeror is privileged to make no offer at all, or a power limited as he desires, he may prescribe acts that are wholly impossible or are very difficult. If the prescribed acts are totally impossible, there is in fact no power at all. So, if $A$ apparently offers to contract with $B$, but prescribes that $B$ must accept yesterday or must accept by going to the moon, no contract can be made. It seems rather fanciful to say that $B$ has a legal power to accept but has not the physical capacity to exercise it. If the prescribed mode of acceptance was that $B$ should lift a I,000 Ib. weight, it would not seem so fanciful. $B$ may not at present have the physical capacity to lift the weight, but others have such capacity and B himself may acquire it. The act of going to the moon is also not wholly inconceivable, but the only individual capable of such a Cyclopean undertaking is Noman. The act of accepting yesterday requires the turning back of time and the living of history over again. This seems wholly inconceivable, although Mark Twain's Connecticut Yankee apparently accomplished the feat.

If a particular mode of acceptance has been prescribed by the offeror, the offeree can bring about contractual relations only by acting exactly in the mode prescribed. Nothing else will be "equally as good." 65 It makes no difference how difficult or expensive the prescribed acts may be, except so far as the difficulty or expense may be evidence to indicate that the acts were not in fact prescribed.

\footnotetext{
63 Brian, C.J., once said: "It is trite law that the thought of man is not triable, for even the devil does not know what the thought of man is." Very likely he was mistaken in each of the two statements. See Ashley, Contracts, pp. $5 \mathrm{I}, 52$.

64 Thus, silence, in addition to a retention of possession of goods, has been held to be an acceptance. Wheeler $v$. Klaholt (I90I) I78 Mass. I4r. The case may well be criticised on the ground that the offeror had prescribed a particular mode of acceptance, while the offeree had not used that mode and the offeror had no reason to suppose that he had.

os Eliason v. Henshaw (I8I9) 4 Wheat. (U. S.) 225.
} 
Of course society is quite capable of creating powers in $B$ whereby he can create other legal relations with $A$, even though $B$ wholly disregards the expressed will of $A$; but in such case we do not call those new legal relations contractual. It is here that we reach the boundary line between contract and noncontract.

No Prescribed Acts. Instead of being expressly limited, the offer may prescribe no mode of acceptance whatever. There must be enough to indicate that the offeror intends to create a power of acceptance, but this is quite possible in the absence of any suggestion whatever as to the mode of acceptance. In this case the offeree may accept in any manner that the law deems to be reasonable under the circumstances.

An even larger power of acceptance may be created by the offeror. He may suggest and authorize an acceptance in one or more particular modes, without making them exclusive. In such case, compliance with the suggested mode will close the contract, however unreasonable or unusual the mode may be; but so also will compliance with any other mode that the law deems to be reasonable. In this case, the offeree has all the power that he would have if the mode of acceptance had been exactly prescribed; and in addition thereto, all the power that he would have if no mode of acceptance had been mentioned at all.

The foregoing rules of acceptance are applicable to all kinds of contracts alike, unilateral and bilateral; but in their application certain distinctions are to be observed and some difficulties must be overcome. It is not always easy to determine what mode of acceptance the offeror has required or suggested; a reasonable construction must be put upon his words or other conduct. If the offeror has prescribed no mode of acceptance and if the offeree has not adopted some mode suggested by the offeror, it must be determined whether or not the mode actually adopted is to be deemed reasonable.

Notice. There is some conflict on the question of notice of acceptance. Is the starting of such a notice by the offeree, ${ }^{88}$ or the receipt of such a notice by the offeror, one of the necessary operative facts? This question is to be answered by an application of the foregoing principles. The offeror may prescribe either or both as a part of the mode of acceptance. If he does

\footnotetext{
${ }^{66}$ This means the doing of an act that will, in the ordinary course of events, make the offeror aware of the acceptance.
} 
so, the prescribed fact is a sine qua non, whether the proposed contract is unilateral or bilateral. ${ }^{67}$ If, however, the offeror prescribes some particular mode of acceptance, not including a notice, none should be required. This is very generally the case where the offeror requests a return performance but no return promise; and it is generally not the case where he requests a return promise. If $\mathrm{A}$ offers his promise of a reward in return for the capture of a felon, or for the destruction of a noxious animal, or for the act of procuring some one to buy certain land, ${ }^{68}$ or for the winning of a race, ${ }^{69}$ or for the buying and using of a smoke ball and catching the influenza, ${ }^{70}$ the acts requested are clearly indicated, and the contract is complete without any act like mailing a notice, and without actual knowledge by the offeror. If $\mathrm{A}$ offers his promise of guaranty in return for B's act of advancing money to $C$, the contract is complete when $B$ has advanced the money. ${ }^{71}$ Where, however, $A$ offers either a promise or a performance in return for a promise to be made by $\mathrm{B}, \mathrm{A}$ does not usually specify any mode of acceptance. In such case, what is the reasonable mode required by the laws? It is a matter of course that $\mathrm{B}$ must do some overt act that expresses his intention to accept, but this, in itself, is not enough. The act must be one that $B$ is justified in believing will bring notice to $A$. In this case, such is the reasonable mode required by the law, because $A$ has asked for a promise-for an assurance upon which he can rely. He cannot rely upon it without knowledge, and it is therefore the custom of reasonable men to do acts that may be expected to give notice to the offeror. It has been vigorously asserted that the contract is not completed until receipt of this notice by the offeror, ${ }^{72}$ but the authority against such a

${ }^{07}$ Lewis v. Browning (188I) I30 Mass. 173.

6s Harson v. Pike (186I) I6 Ind. I40.

${ }^{69}$ Alvord v. Smith (1878) 63 Ind. 58.

${ }^{70}$ Carlill v. Carbolic Sinoke Ball Co. [1893] I Q. B. 256.

71 Bishop v. Eaton (1894) I6I Mass. 496; Somersall v. Barneby (16I1)

Cro. Jac. 287. The sending of a notice by mail may, by construction of law, be made a condition precedent to a right of action on the guaranty; but this does not make the notice a part of the process of acceptance. The courts are in confusion on this. See Ames, Cases on Suretyship, p. $225 \mathrm{ff}$.

${ }^{72}$ Langdell, Stsmmary of Cont., sec. I4; Bramwell, L. J. dissenting in Household, etc. Ins. Co. v. Grant (1879) 4 Ex. D. 216; McCulloch v. Eagle Ins. Co. (1822) I Pick (Mass.) 278; Wald's Pollock, Contracts (3d. ed.) p. 37 . 
doctrine is now overwhelming, both in England and American. ${ }^{73}$ This fact shows that the criticisms of the prevailing rule are based upon some a priori theory of contract that is not in harmony with human desires and the other facts of life.

What acts are those that may reasonably be regarded as sufficient in the effort to bring knowledge of the acceptance to the offeror? If the parties are negotiating in each others' presence, the act must be one that will bring immediate knowledge. The offeree could not accept by mailing a letter, because in the absence of an extended time for acceptance, such a mode would be unreasonable and unusual. In choosing his mode of acceptance, the offeree must consider the time of delivery, the place of delivery, the certainty of arrival, and the intelligiblity of the expression. If, considering these things, the offeree chooses the customary mode, it is sufficient. It may be sufficient to mail a letter, even though the offer was made orally, if several days were allowed for acceptance. ${ }^{74}$ The starting of a telegram by the usual telegraph companies would be equally effective, and in some instances would be effective where the mailing of a letter would not be. If the offer itself was made by mail, it has been supposed that this made the post office an agent of the offeror to receive the letter of acceptance. This theory has been disapproved and seems to have little to support it. It is better to base the rule upon the "usage of trade,"75 or "the ordinary usages of mankind."76

So much has been said about the necessity and propriety of mailing a letter of acceptance that it is often taken to be universally required, even where the offeror has himself prescribed another mode of acceptance. ${ }^{7 T}$

\section{MUTUAL ASSENT}

The rule generally laid down is that the acts of offer and acceptance must be expressions of assent. This has long been the

\footnotetext{
${ }^{73}$ See cases cited in Wald's Pollock, Contracts (3d ed.) p. 39, note 42. See also Jap. Civil Code, art. 526.

${ }^{74}$ Henthorn v. Fraser [1892] 2 Ch. 27.

${ }^{75}$ Dunlop v. Higgins ( 1848 ) I H. L. Cas. 38I.

${ }^{76}$ Henthorn v. Fraser, supra; see also German Civil Code, sec. I5I.

${ }^{77}$ Household etc. Ins. Co. v. Grant (1879) 4 Ex. D. 216; In re London and Northern Bank [1900] I Ch. 220. But Mr. Justice Holmes said in Leinox v. Murphy ( 1898 ) I7I Mass. 370: "There is no universal doctrine of the common law . . . . that acceptance of an offer must be communicated."
} 
theory upon which contractual obligations have been enforced. the test question usually put is, what was the intention of the parties? It must not be supposed from this, however, that no contractual relation can exist unless the parties both foresaw and intended it. If two parties have gone through the form of offering and accepting, the law determines the legal relations that follow. Frequently these come with surprise and shock to the parties themselves. It may be said here, as in the law of torts, that the parties are presumed to intend the consequences of their acts, but this is often a violent presumption contrary to fact. To indulge such a presumption is merely to hold that the actual intention of the parties is not the determinative fact, or even that it is wholly immaterial.

Parties are bound by the reasonable meaning of what they said and not by what they thought. If $A$ makes an offer to $B$ which $B$ reasonably understands to have a particular meaning, and so accepts, $A$ is bound in accordance with B's understanding. ${ }^{78}$ So also, if A's offer has only one reasonable meaning, $B$ is bound in accordance therewith, even though he accepted supposing the meaning to be otherwise. The operative act creating an obligation is the expression of intention and not the thought process. ${ }^{79}$ It may be said that the purpose of the rule is to carry out the intentions of the parties in the great majority of cases $;^{80}$ but it seems better to say that its purpose is to secure the fulfilment of the promisee's reasonable expectations as induced by the promisor's act. ${ }^{81}$ In the law of contract as in the law of tort, men are expected to live up to the standard of the reasonably prudent man. $^{82}$ If there is a misunderstanding and neither party

${ }^{78}$ Mansfield v. Hodgdon (I888) I47 Mass. 304.

${ }^{79}$ See Holland, Jurisprudence (roth ed.) p. 253; cf. Anson, Contracts (2d Am. ed., Huffcut) p. ro. "As to the rule that the wills of the contracting parties must concur, it only means that they must concur in legal contemplation." Langdell, Summary of the Law of Contracts, sec. I80; see also secs. 148, 149.

80 See Anson, cited in preceding note.

81 Holland, Juris. (roth ed.) p. 253.

82 Where an acceptance was so worded that the offeror thought it conditional, there was no contract even though the acceptor intended no condition. "If it be true that respondent did not mean to convey such an idea, but used language leading Mr. Hawley, in the exercise of ordinary care, to suppose it did, it must bear the burden of its fault. $\mathrm{He}$ had a right to act upon the meaning which the respondent's words con- 
was negligent, there is no contract.s ${ }^{33}$ The same is true if both are equally negligent. ${ }^{84}$

The legal relations consequent upon offer and acceptance are not wholly dependent, even upon the reasonable meaning of the words and acts of the parties. The law determines these relations in the light of subsequent circumstances, these often being totally unforeseen by the parties. In such cases it is sometimes said that the law will create that relation which the parties would have intended had they foreseen. ${ }^{85}$ The fact is, however, that the decision will depend upon the notions of the court as to policy, welfare, justice, right and wrong, such notions often being inarticulate and subconscious. ${ }^{80}$

YALE UnIVERSiTy, School of LAw.

Arthur L. Corbin.

veyed to him, if such, reasonably, night be the meaning an ordinarily careful person would read out of such language." Jacob Johnson Fish Co. v. Hazuley (1912) 150 Wis. 578.

83 Raffles v. Wichelhaus ( 1864 ) 2 H. \& C. 906.

84 Falck v. Williams [1900] A. C. I76; Pecrless Glass Co. v. Pacific Co. (I898) I2I Cal. 64I; cf. German Civil Code, secs. II9, I22.

${ }_{85}$ "Supposing a contract to have been duly formed, what is its result? An obligation has been created between the contracting parties, by which rights are conferred upon the one and duties are imposed upon the other, partly stipulated for in the agreement, but partly also implied by law, which, as Bentham observes (Works III, I90) "has thus in every country supplied the shortsightedness of individuals, by doing for them what they would have done for themselves, if their imagination had anticipated the march of nature." Holland, Juris. (Ioth ed.) p. 278 . In Leonard v. Dyer (1857) 26 Conn. 172, 178, the court said: "And if we were to add stipulations to the contract which the parties themselves did not make, it appears to us that such only should be inferred as the parties themselves would have made, had they foreseen the circumstances that rendered such stipulations important." See also Bankes, L. J., in Grove v. Webb (I9I6) II4 L. T. 1082, 1089.

88 "You can always imply a condition in a contract. But why do you imply it? It is because of some belief as to the practice of the community or of a class, or because of some opinion as to policy, or, in short, because of some attitude of yours upon a matter not capable of exact quantitative measurement, and therefore not capable of founding exact logical conclusions." Justice Holmes, The Path of the Law, to HArv. L. REv. 466. 